\title{
Argon Plasma Coagulation for the Treatment of Chronic Radiation Proctitis - real-world Data from Indonesian National Cancer Center
}

\author{
Lianda Siregar, Imelda Maria Loho, Agus Sudiro Waspodo, Rahmanandhika Swadari, \\ Benedicta Audrey Maharani \\ Department of Gastroentero-hepatology, Dharmais Hospital, \\ Indonesian National Cancer Center, Jakarta
}

\author{
Corresponding author: \\ Lianda Siregar. Department of Gastroenterology and Hepatology, Dharmais Hospital, Indonesian National \\ Cancer Center. Jl. Let. Jend. S. Parman Kav 84 - 86 Jakarta Indonesia. Phone/facsimile: +62-21-5681570. \\ E-mail:liandadr.siregar@yahoo.com
}

\begin{abstract}
Background: This study aimed to evaluate the endoscopic features and clinical outcome of patients with chronic radiation proctitis (CRP) at one year after argon plasma coagulation (APC) treatment.

Method: Between March 2016 and September 2019, a total of 48 female patients with CRP were treated with $A P C$ and their medical records were retrospectively reviewed. APC treatment was done every 3 to 54 weeks, with a median of 8 weeks. Number of APC was decided by the treating physician according to the severity of illness. Endoscopic and clinical features at one year after the final APC were recorded as the effectiveness of APC.

Results: Of 48 patients, 26 patients were included in this study. Number of APC sessions varied between 1 to 5 sessions of APC for each patient. Of 26 patients, 22 patients achieved clinical improvement and four patients did not achieve clinical improvement at one year after the last APC session. Of the four patients who failed to achieve clinical improvement, two patients underwent surgery, one patient had occasional mild rectal bleeding, and one patient required regular transfusion. Of 22 patients with clinical improvement at one-year after the last APC, improvement of endoscopic features was found in 20 patients. Of four patients who did not achieve endoscopic improvement, diagnostic colonoscopy showed telangiectasis of more than $50 \%$ of rectal surface in 1 patient, presence of blood in 2 patients, and presence of ulceration of $<1 \mathrm{~cm}$ in 1 patient.
\end{abstract}

Conclusion: $A P C$ is an effective treatment option for CRP.

Keywords: Argon plasma coagulation, chronic radiation proctitis, treatment, endoscopy

\section{ABSTRAK}

Latar belakang: Studi ini bertujuan untuk mengevaluasi gambaran endoskopi dan klinis pasien dengan proktitis radiasi kronik (PRK) setelah satu tahun mendapat terapi argon plasma coagulation (APC).

Metode: Pengumpulan data rekam medis secara rektrospektif dilakukan pada 48 pasien wanita dengan PRK yang diterapi dengan APC pada bulan Maret 2016 sampai September 2019. Terapi APC dilakukan setiap 3 sampai 54 minggu, dengan median 8 minggu. Frekuensi APC ditentukan oleh dokter yang merawat sesuai dengan tingkat keparahan penyakitnya. Gambaran endoskopi dan klinis setelah satu tahun mendapat APC terakhir dinilai untuk melihat manfaat APC.

Hasil: Dari 48 pasien, 26 pasien memenuhi kriteria dalam penelitian ini. Jumlah sesi APC bervariasi antara 1 - 5 sesi per pasien. Dari 26 pasien, perbaikan gambaran klinis setelah satu tahun pasca terapi APC terakhir 
didapatkan pada 22 pasien, sedangkan empat pasien gagal mencapai perbaikan klinis. Dari empat pasien yang gagal mencapai perbaikan klinis, dua pasien menjalani operasi, satu pasien masih mengalami perdarahan rektal ringan, dan satu pasien menjalani transfusi darah berkala. Dari 22 pasien dengan perbaikan klinis, perbaikan gambaran endoskopik didapatkan pada 20 pasien. Gambaran endoskopik awal pada empat pasien yang tidak mencapai perbaikan gambaran endoskopik adalah telangiectasis $>50 \%$ permukaan rectum pada 1 pasien, adanya darah segar pada kolonoskopi awal ditemukan pada 2 pasien, dan adanya ulserasi $<1 \mathrm{~cm}$ ditemukan pada 1 pasien.

Simpulan: Terapi APC merupakan terapi yang efektif untuk PRK.

Kata kunci: Argon plasma coagulation, proktitis radiasi kronik, terapi, endoskopi

\section{INTRODUCTION}

Radiotherapy is widely used in patients with pelvic malignancy, such as, cervical, prostate, and rectal cancer. ${ }^{1}$ Chronic radiation proctitis (CRP) occurs in about $2-20 \%$ of patients with pelvic malignancy following radiotherapy. ${ }^{2-5}$ Although many modalities of treatment are used for treating CRP, there is no standard treatment for CRP based on the pattern and severity of the disease. The pathophysiology of CRP is unknown and may involve obliteration of endarteritis and chronic ischemia. ${ }^{6,7}$

The most common symptoms of CRP are diarrhea, rectal bleeding, stricture, and tenesmus. The most common endoscopic feature of CRP is telangiectasia due to ischemia mechanism. Superficial vascular lesion may result in mild or severe rectal bleeding, requiring blood transfusion. ${ }^{6}$

CRP management can be divided into two categories: invasive treatment (anti-inflammatory, sucralfate, short chain fatty acid, hyperbaric oxygen therapy, antioxidant) and invasive treatment (ablation and surgery).$^{6,8}$ Although there are various modalities of treatment, there is no standard treatment for CRP. Argon plasma coagulation (APC) is used to ionize the argon gas that coagulates telangiectasis vessels. Available studies showed a significant improvement of symptoms after several APC sessions. ${ }^{7}$

\section{METHOD}

Medical records of 48 patients with CRP treated with APC in our hospital between 2016 and September 2019, were retrospectively reviewed. Inclusion criteria was patients with anal bleeding due to CRP and treated with APC between March 2016 to September 2019, without any other cause of lower gastrointestinal bleeding proven after complete colonoscopy to caecum. The exclusion criteria were the lack of data in patients with CRP, including blood transfusion status and clinical features at one year after the last APC session. Improvement of APC was evaluated according to endoscopic and clinical features at one year after the last APC session. Clinical improvement was defined as improvement of rectal bleeding without any requirement of blood transfusion and no symptoms of bowel obstruction.

A total sampling method was performed. Colonoscopy was conducted in all patients prior to initiation of APC to exclude other etiologies of lower gastrointestinal bleeding and to determine the severity of mucosal lesions. Patients underwent bowel preparation with PEG-ELS (Niflec $\left.{ }^{\circledR}\right)$ solution containing $5.7 \mathrm{~g}$ sodium sulfate, $1.7 \mathrm{~g}$ sodium bicarbonate, $1.5 \mathrm{~g}$ sodium chloride, and $59.0 \mathrm{~g}$ macrogol 4000 per liter. Patients were instructed to drink $2 \mathrm{~L}$ of PEG-ELS solution at a rate of $1 \mathrm{~L} / \mathrm{h}$ on the evening (up to $10 \mathrm{pm}$ ) and $2 \mathrm{~L}$ of PEG-ELS solution 4 to 6 hours prior to the colonoscopy. Propofol and fentanyl sedation was used to reduce patients' discomfort during the procedure. The equipment used was an electrosurgical unit (ERBE VIO 300D, ERBE Elektromedizin GmBH, USA) with forced APC modes and circumferential APC probe, inserted through the working channel of the flexible sigmoidoscope used for APC application. The argon flow rate and the electrical power were set at $2.0 \mathrm{~L} / \mathrm{min}$ and $45 \mathrm{~W}$.

\section{RESULTS}

Between March 2016 and September 2019, a total of 48 female patients with chronic radiation proctitis received APC treatment and 26 patients with a median age of 60.5 years (range 49-80) were included in this study. No male patient was found during this period. As many as 10 patients were deceased due to progression of their primary cancer, and 12 patients were lost to follow up. All patients had undergone radiotherapy as a part of gynecological malignancy treatment. There were 23 patients with cervical cancer, two patients with endometrium cancer, and one patient with vulva cancer. All patients had chronic hematochezia and seven patients required blood transfusion due to proctitis related anemia. Two patients and one patient 
were on anticoagulant and antiplatelet, respectively. On diagnostic colonoscopy, there were 13 patients with endoscopic features of telangiectasis on more than $50 \%$ of surface area, 10 patients with presence of fresh blood, 1 patient with ulceration $<1 \mathrm{~cm}$, and 1 patient with ulceration $>1 \mathrm{~cm}$. Other comorbidities, such as, hypertension, diabetes mellitus, and hyperlipidemia were found in five patients. (Table 1)

Table 1. Baseline characteristic of CRP patients prior to treatment

\begin{tabular}{|c|c|}
\hline Variable & $\begin{array}{l}\text { Number of } \\
\text { patients } \\
(n=26)\end{array}$ \\
\hline \multicolumn{2}{|l|}{ Gender } \\
\hline Female & 26 \\
\hline \multicolumn{2}{|l|}{ Age } \\
\hline Median (range), years & $60.5(49-80)$ \\
\hline \multicolumn{2}{|l|}{ Patients requiring blood transfusion } \\
\hline Yes & 7 \\
\hline \multicolumn{2}{|l|}{ Endoscopic features before APC } \\
\hline Telangiectasis $<50 \%$ & 1 \\
\hline Telangiectasis $>50 \%$ & 13 \\
\hline Presence of fresh blood & 10 \\
\hline Ulceration $<1 \mathrm{~cm}$ & 1 \\
\hline Ulceration $>1 \mathrm{~cm}$ & 1 \\
\hline \multicolumn{2}{|l|}{ Comorbidities } \\
\hline Diabetes mellitus & 2 \\
\hline Hyperlipidemia and hypertension & 1 \\
\hline Diabetes mellitus and hypertension & 1 \\
\hline Hyperlipidemia & 1 \\
\hline \multicolumn{2}{|c|}{ Ongoing anticoagulation or antiplatelet therapy } \\
\hline Aspirin & 1 \\
\hline Warfarin & 1 \\
\hline Rivaroxaban & 1 \\
\hline
\end{tabular}

The patients were followed-up for 12 months after the last APC session. Of 26 patients, 22 patients achieved clinical improvement and four patients did not achieve clinical improvement at one year after the last APC session. Of the four patients who failed to achieve clinical improvement, two patients underwent surgery, one patient had occasional mild rectal bleeding, and one patient required regular transfusion. Of 22 patients with clinical improvement at one-year after the last APC, improvement of endoscopic features was found in 20 patients. Number of APC sessions varied between 1 to 5 sessions of APC for each patient. Of four patients who did not achieve endoscopic improvement, diagnostic colonoscopy showed telangiectasis of more than $50 \%$ of rectal surface in 1 patient, presence of blood in 2 patients, and presence of ulceration of $<$ $1 \mathrm{~cm}$ in 1 patient. Of 26 patients, 7 patients required blood transfusion during their clinical course of disease. Endoscopic findings of seven patients who required blood transfusion were telangiectasis $>50 \%$ of rectal surface ( 3 patients), presence of fresh blood (3 patients), and ulceration of $>1 \mathrm{~cm}$ (1 patient). However, these seven patients achieved clinical improvement. Comparison between those with and without blood transfusion is depicted in Table 2.
Table 2. Comparison of baseline parameters between patients needing blood transfusion and not needing blood transfusion

\begin{tabular}{lll}
\hline Parameters & $\begin{array}{l}\text { Patients with } \\
\text { blood transfusion } \\
(\mathbf{n}=\mathbf{7})\end{array}$ & $\begin{array}{l}\text { Patients without } \\
\text { blood transfusion } \\
(\mathbf{n}=19)\end{array}$ \\
\hline $\begin{array}{l}\text { Endoscopic feature } \\
\text { Telangiectasis }<50 \%\end{array}$ & 0 & 1 \\
Telangiectasis $>50 \%$ & 3 & 10 \\
Presence of fresh blood & 3 & 7 \\
Ulceration $<1 \mathrm{~cm}$ & 0 & 1 \\
$\quad$ Ulceration $>1 \mathrm{~cm}$ & 1 & 0 \\
Number of APC sessions & & \\
One & 2 & 8 \\
Two & 1 & 3 \\
Three & 0 & 3 \\
Four & 2 & 2 \\
Five & 2 & 3 \\
Clinical improvement & 7 & 15 \\
Anticoagulation & & \\
Aspirin & 0 & 1 \\
Warfarin & 0 & 1 \\
Rivaroxaban & 0 & 1 \\
\hline
\end{tabular}

\section{DISCUSSION}

The CRP incidence rate in patients with history of pelvic radiation therapy is between 2 to $20 \%$, with rectal bleeding as the most common complication. ${ }^{2-5}$ Inflammation and damage to the rectum wall after ionizing radiation precede tissue fibrosis and obliterative endarteritis, and finally give rise to chronic mucosal ischemia. ${ }^{7,9}$ Finally neovascularization and telangiectasias that arise from the tissue ischemia may induce rectal bleeding, stricture formation, fistulization, ulceration, and in some severe cases perforation. The primary aim of CRP treatment is to control bleeding. There are many options for CRP treatment but until now there is no standard therapy. APC is one of the options for CRP treatment using high frequency energy (monopolar diathermy) that is transmitted to the tissue by ionized gas to control the bleeding by cauterizing mucosal telangiectasias. In this study, we showed that APC treatment is effective in treating patients with CRP.

Telangiectasis of more than $50 \%$ of rectal surface is considered an independent prognostic factor for APC failure. ${ }^{6}$ However, in our study, of six patients who did not achieve endoscopic improvement, telangiectasis of more than $50 \%$ of rectal surface was found in 1 patient, while presence of blood and presence of ulceration of $<1 \mathrm{~cm}$ were found in 2 patients and 1 patient, respectively. Unfortunately, a statistical analysis to establish the prognostic factor of APC failure could not be conducted in our study due to limited sample size.

There is a lack of data regarding combination of adjuvant medical therapy such as steroid or 5-aminosalicylic with APC. In patients failing other various medical treatment, APC is shown to be effective in controlling rectal bleeding and improving anemia. ${ }^{10}$ Tjandra et al showed that of 12 patients 
receiving APC after failed formalin therapy, 10 patients had improvement of the severity and frequency of bleeding. ${ }^{8}$ On the other hand, patients with severe radiation proctitis but failing with several sessions of APC, could have clinical improvement with subsequent single formalin treatment session. ${ }^{11}$

In our study, the number of APC session to achieve clinical improvement varied between one to five sessions and all patients who underwent one session of APC had clinical improvement. Zhong et al showed that the optimal amount of APC sessions is unknown. ${ }^{2}$ Grading based on endoscopic feature could not predict the number of APC sessions needed to stop rectal bleeding. ${ }^{12}$ Swan et al showed significant clinical improvement in rectal bleeding around $68 \%$ in first session of APC and $96 \%$ in second session of APC. ${ }^{13}$ Karmanolis et al reported that in patients who underwent two sessions of APC, rectal bleeding ceased completely in $89,3 \%$ (50/56) patients. ${ }^{14}$ However, in our study there were only 10 of 26 patients (38\%) who needed one session of APC to achieve clinical improvement.

There were 7 patients who needed blood transfusion and their endoscopic findings were telangiectasis $>50 \%$ of rectal surface (3 patients), presence of fresh blood (3 patients), and ulceration of $>1 \mathrm{~cm}$ ( 1 patient). This was in line with other study which reported confluent lesions, presence of blood, and ulceration as endoscopic features of patients needed blood transfusion. ${ }^{7}$ In this study, three patients were treated with anticoagulant medicine but all of them achieved clinical improvement and did not require any blood transfusion after APC. Weiner et al reported that patients with anticoagulation were at increased risk of blood transfusions and Karamanolis et al showed that patients with anticoagulation had a risk of bleeding recurrence. ${ }^{8,9}$

Our study has several limitations. First, this is a retrospective study with a small number of cases. Second, the variability between the treating physicians in conducting an APC session could not be avoided. The efficacy of APC has been studied in a randomized controlled trial and compared with other treatment modalities, such as bipolar electrocoagulation or topical formalin, but those studies only included small number of patients. ${ }^{15,16} \mathrm{~A}$ randomized-controlled trial with a larger number of patients will allow comparison of APC alone or in combination with other treatment modalities.

\section{CONCLUSION}

APC is an effective treatment option for CRP.

\section{REFERENCES}

1. Navarro CS, Bustamante FA, Moura EG, Bernardo WM, Nobre R, Ide E, et al. Comparison of endoscopic therapies for chronic radiation proctitis: a systematic review and metaanalysis. J Adenocarcinoma 2016;1:1-8.

2. Cho KH, Lee CK, Levit SH. Proctitis after conventional for prostate cancer : importance of minimizing posterior rectal dose. Radiology 1995;195:699-703.

3. Lanciano RM, Martz K, Montana GS, Hanks GE. Influence of age, prior abdominal surgery, fraction size, and dose on complications after radiation therapy for squamous cell cancer of the uterine cervix. A patterns of care study. Cancer 1992;69:2124-30.

4. Perez CA, Fox S, Lockett MA, Grigsby PW, Camel HM, Galakatos A, et al. Impact of dose In outcome of irradiation alone in carinoma of uterine cervix: analysis of two different methods. Internatioan J Radiat Oncol 1991;21:885-98.

5. Tagkalidis PP, Tjandra JJ. Chronic radiation proctitis. ANZ J Surg 2001;71:230-7.

6. Zhong QH, Liu ZZ, Yuan ZX, Ma TH, Huang XY, Wang $\mathrm{HM}$, et al. Efficacy and complications of argon plasma coagulation for hemorrhagic chronic radiation proctitis. World J Gastroenterol 2019;9327:1618-27.

7. Sudha SP, Kadambari D. Efficacy and safety of argon plasma coagulation in the management of extensive chronic radiation proctitis after pelvic radiotherapy for cervical carcinoma. Int J Color Dis 2017;32:1285-8.

8. Postgate A, Saunders B, Tjandra J, Vargo J. Argon plasma coagulation in chronic radiation proctitis. Endoscopy 2007;39:361-5.

9. Grodsky MB, Sidani SM. Radiation proctopathy. Clin Colon Rectal Surg 2015;28:103-11.

10. Villavicencio RT, Rex DK, Rahmani E. Efficacy and complications of argon plasma coagulation for hematochezia related to radiation proctopathy. Gastrointest Endosc 2002;55:70-4.

11. Zinicola R, Rutter MD, Falasco G, Brooker JC, Cennamo V, Contini $\mathrm{S}$, et al. Haemorrhagic radiation proctitis: endoscopic severity may be useful to guide therapy. Int J Colorectal Dis 2003;18:439-44.

12. Siow SL, Mahendran HA, Seo CJ. Complication and remission rates after endoscopic argon plasma coagulation in the treatment of haemorrhagic radiation proctitis. Int J Colorectal Dis 2017;32:131-4.

13. Swan MP, Moore GTC, Sievert W, Devonshire DA. Efficacy and safety of single-session argon plasma coagulation in the management of chronic radiation proctitis. YMGE 2010;72:150-4.

14. Karamanolis G, Triantafyllou K, Tsiamoulos Z, Polymeros D, Kalli T, Misailidis N, et al. Argon plasma coagulation has a long-lastingtherapeutic effect in patients with chronic radiation proctitis. Endoscopy 2009;41:529-31.

15. Lenz L, Tafarel J, Correia L, Bonilha D, Santos M, Rodrigues $\mathrm{R}$, et al. Comparative study of bipolar eletrocoagulation versus argon plasma coagulation for rectal bleeding due to chronic radiation coloproctopathy. Endoscopy 2011;43:697-701.

16. Alfadhli AA, Alazmi WM, Ponich T, Howard JM, Prokiopiw I, Alaqeel A, et al. Efficacy of argon plasma coagulation compared with topical formalin application for chronic radiation proctopathy. Can J Gastroenterol 2008;22:129-32. 